\title{
MODEL COLLABORATION: UNIVERSITY LIBRARY SYSTEM AND REHABILITATION RESEARCH TEAM TO ADVANCE TELEPRACTICE KNOWLEDGE
}

\author{
TIMOTHY S. DELIYANNIDES, MSIS, VANESSA GABLER, BA \\ OFFICE OF SCHOLARlY COMMUNICATION AND PUBLISHING, UNIVERSITY LIBRARY SYSTEM, \\ UNIVERSITY OF PITTSBURGH
}

\section{ABSTRACT}

This Publisher's Report describes the collaboration between a university library system's scholarly communication and publishing office and a federally funded research team, the Rehabilitation Engineering Research Center (RERC) on Telerehabilitation. This novel interdisciplinary collaboration engages librarians, information technologists, publishing professionals, clinicians, policy experts, and engineers and has produced a new Open Access journal, International Journal of Telerehabilitation, and a developing, interactive web-based product dedicated to disseminating information about telerehabilitation. Readership statistics are presented for March 1, 2011 - February 29, 2012.

Keywords: telerehabilitation, Open Access journal

\section{THE LIBRARY AS A SUPPORTER OF RESEARCHERS}

As part of its mission to "support researchers in the production and sharing of knowledge in a rapidly changing publishing industry" the University Library System, University of Pittsburgh (ULS) has partnered with the Rehabilitation Engineering and Research Center (RERC) on Telerehabilitation to produce the International Journal of Telerehabilitation (IJT). In its role as publisher, the ULS seeks to transform the traditional subscription-based model of scholarly communication, promote the principle of Open Access to scholarly research, and incentivize scholars worldwide to join in this commitment.

This novel interdisciplinary collaboration engages librarians, information technologists, publishing professionals, practitioners, researchers, policy experts, and engineers.

\section{INTERNATIONAL JOURNAL OF TELEREHABILITATION (IJT)}

Established in 2008, the IJT is one of the first scholarly journals to publish peer-reviewed research specifically focused on telerehabilitation and includes original research, case studies, technical reviews, and policy papers. The IJT is published biannually and has thus far produced six issues and a pre-publication issue. Articles are vetted through a rigorous peer-review process for quality and then offered free of charge to the world through Open Access immediately upon publication. Authors retain copyright to their works through a Creative Commons license. No author fees are charged by the journal, further reducing the barriers to publish.

The IJT provides an accessible version of all published articles formatted to work well with text-to-speech software. For non-textual content, the accessible version includes language that conveys a detailed description of the information contained within the graph, table, or image.

The Open Journal Systems (OJS) software enables the flow of scholarly content from initial author submissions through online publication and indexing. The platform provides a set of reading tools to extend the use of scholarly content through RSS feeds and postings to Facebook, Twitter, and other social media so that potential readers can discover journal articles via blogs, databases, search engines, and library collections.

The IJT is registered with several major indexing and abstracting services, such as the Directory of Open Access Journals, a collection of free full-text qualitycontrolled scientific and scholarly journals; Ulrich's, the global source for periodicals; EBSCO Discovery Services, one of the world's premiere abstracting and indexing services for scholarly content; and the Open Archives Registry; and others. 
Data about the IJT's readership was generated on April 2, 2012 at 3:21 p.m. using Affinium Netlnsight 7.3 (Copyright @) 1996-2008 Unica Corporation) for Web activity between March 1, 2011-February 29, 2012, including: user domains; visitor hits; total page views; most frequent referrers; robot/spider summary; and temporal and browser summaries.

As depicted in Table 1, the IJT was viewed 44,843 times between March 1, 2011-February 29, 2012, with 202,290 total visits. Readers from over 40 countries accessed IJT during this period, with the top ten being: United States, Russian Federation, Ukraine, United Kingdom, Latvia, Germany, Italy, Australia, Poland, and France.

\begin{tabular}{|c|c|c|}
\hline Domain & Views & Visits \\
\hline Unresolved & $71,050(35.1 \%)$ & $17,373(38.7 \%)$ \\
\hline Network (.net) & $33,508(16.6 \%)$ & $7,831(17.5 \%)$ \\
\hline Commercial (.com) & $26,358(13.0 \%)$ & $6,405(14.3 \%)$ \\
\hline Russian Federation & $14,330(7.1 \%)$ & $3,391(7.6 \%)$ \\
\hline United States Educational & $25,132(12.4 \%)$ & $2,015(4.5 \%)$ \\
\hline Ukraine & $7,739(3.8 \%)$ & $1,766(3.9 \%)$ \\
\hline Organization (.org) & $1,255(0.6 \%)$ & $523(1.2 \%)$ \\
\hline United Kingdom & $1,841(0.9 \%)$ & $344(0.8 \%)$ \\
\hline Latvia & $1,155(0.6 \%)$ & $342(0.8 \%)$ \\
\hline Germany & $1,173(0.6 \%)$ & $287(0.6 \%)$ \\
\hline Italy & $1,291(0.6 \%)$ & $274(0.6 \%)$ \\
\hline Australia & $1,325(0.7 \%)$ & $263(0.6 \%)$ \\
\hline Poland & $1,260(0.6 \%)$ & $249(0.6 \%)$ \\
\hline France & $871(0.4 \%)$ & $249(0.6 \%)$ \\
\hline Brazil & $366(0.2 \%)$ & $215(0.5 \%)$ \\
\hline Romania & $528(0.3 \%)$ & $197(0.4 \%)$ \\
\hline Canada & $1,451(0.7 \%)$ & $184(0.4 \%)$ \\
\hline China & $678(0.3 \%)$ & $170(0.4 \%)$ \\
\hline Japan & $485(0.2 \%)$ & $152(0.3 \%)$ \\
\hline European Union & $548(0.3 \%)$ & $112(0.2 \%)$ \\
\hline Indonesia & $207(0.1 \%)$ & $110(0.2 \%)$ \\
\hline Netherlands & $457(0.2 \%)$ & $100(0.2 \%)$ \\
\hline Switzerland & $321(0.2 \%)$ & 95 (0.2\%) \\
\hline Georgia & $482(0.2 \%)$ & $92(0.2 \%)$ \\
\hline South Africa & $435(0.2 \%)$ & $90(0.2 \%)$ \\
\hline Belarus & $407(0.2 \%)$ & $88(0.2 \%)$ \\
\hline Honduras & $440(0.2 \%)$ & $84(0.2 \%)$ \\
\hline
\end{tabular}




\begin{tabular}{|c|c|c|}
\hline Domain & Views & Visits \\
\hline India & $258(0.1 \%)$ & $82(0.2 \%)$ \\
\hline United States Government & $453(0.2 \%)$ & $75(0.2 \%)$ \\
\hline Moldova, Republic of & $240(0.1 \%)$ & $74(0.2 \%)$ \\
\hline United States & $284(0.1 \%)$ & $72(0.2 \%)$ \\
\hline Informational (.info) & $167(0.1 \%)$ & $72(0.2 \%)$ \\
\hline British Indian Ocean Territory & $97(0.0 \%)$ & $71(0.2 \%)$ \\
\hline local & $209(0.1 \%)$ & $70(0.2 \%)$ \\
\hline Spain & $245(0.1 \%)$ & $65(0.1 \%)$ \\
\hline Sweden & $374(0.2 \%)$ & $63(0.1 \%)$ \\
\hline Israel & $302(0.1 \%)$ & $60(0.1 \%)$ \\
\hline Greece & $392(0.2 \%)$ & $57(0.1 \%)$ \\
\hline United States Military & $195(0.1 \%)$ & $43(0.1 \%)$ \\
\hline Colombia & $228(0.1 \%)$ & $42(0.1 \%)$ \\
\hline Thailand & $70(0.0 \%)$ & $41(0.1 \%)$ \\
\hline Mexico & $129(0.1 \%)$ & $38(0.1 \%)$ \\
\hline Hong Kong & $61(0.0 \%)$ & $38(0.1 \%)$ \\
\hline Luxembourg & $148(0.1 \%)$ & $37(0.1 \%)$ \\
\hline Taiwan & $299(0.1 \%)$ & $36(0.1 \%)$ \\
\hline Argentina & $73(0.0 \%)$ & $36(0.1 \%)$ \\
\hline Ireland & $116(0.1 \%)$ & $33(0.1 \%)$ \\
\hline Turkey & $69(0.0 \%)$ & $30(0.1 \%)$ \\
\hline Singapore & $96(0.0 \%)$ & $29(0.1 \%)$ \\
\hline Subtotal for rows 1 - 50 & $199,844(98.8 \%)$ & $44,206(98.6 \%)$ \\
\hline Total for all 132 rows & $202,290(100.0 \%)$ & $44,843(100.0 \%)$ \\
\hline Total for time period & $202,290(100.0 \%)$ & $44,843(100.0 \%)$ \\
\hline
\end{tabular}




\section{DeVelopmental PROJECTS}

The collaboration is also fostering the development of an interactive web-based product dedicated to disseminating information about telerehabilitation. Planned also are content additions to high volume, open source dissemination vehicles such as Wikipedia.

\section{CONCLUSIONS}

This model collaboration exemplifies a best-practice interdisciplinary partnership that could be replicated by institutions worldwide to achieve broader dissemination of peer-reviewed scholarly research results through Open Access. 